\title{
Only Twice as Much: A Rule for Regulating Lenders
}

\author{
Anand V. Swamy and Mandar Oak
}

January 2007

\begin{abstract}
Present-day policies aiming to improve the performance of credit markets, such as grouplending or creation of collateral, typically aim to change incentives for borrowers. In contrast, pre-modern credit market interventions, such as usury laws, often targeted the behavior of lenders. We describe and model a norm which, though widespread, has escaped scholarly attention: a stipulation that accumulated interest cannot exceed the original principal, irrespective of how much time has elapsed. We interpret this rule, which is found in Hindu, Roman, and Chinese legal traditions, as giving lenders the incentive to find more capable borrowers, who will be able to repay early, thereby improving the allocation of capital. We document the consistency between our explanation and the rationale offered by policy-makers.

1065
\end{abstract}




\title{
ONLY TWICE AS MUCH: A RULE FOR REGULATING LENDERS
}

\begin{abstract}
Present-day policies aiming to improve the performance of credit markets, such as group-lending or creation of collateral, typically aim to change incentives for borrowers. In contrast, pre-modern credit market interventions, such as usury laws, often targeted the behavior of lenders. We describe and model a norm which, though widespread, has escaped scholarly attention: a stipulation that accumulated interest cannot exceed the original principal, irrespective of how much time has elapsed. We interpret this rule, which is found in Hindu, Roman, and Chinese legal traditions, as giving lenders the incentive to find more capable borrowers, who will be able to repay early, thereby improving the allocation of capital. We document the consistency between our explanation and the rationale offered by policy-makers.
\end{abstract}

Keywords: Rural Credit Markets, Information Acquisition, Predatory Lending JEL Classification: C7, D8, K1, N2

Date: January 2007.

We would like to thank the seminar participants at NEUDC 2005, Lehigh University, University of Western Ontario, Williams College, Florida Atlantic University and Cornell University. Special thanks to Jonathan Conning, Matt Kotchen, Dilip Mookerjee, Stephen Snyder and Eric Van Tassel for their comments and suggestions. All the remaining errors are solely ours. 


\section{INTRODUCTION}

Much of recent theoretical literature on credit markets in poor economies has focused on problems of moral hazard and adverse selection among borrowers. Measures like group lending and land titling have been proposed, and studied extensively, as possible solutions to these problems. In contrast, descriptions of credit markets by historians, anthropologists, and sociologists, often highlight a different problem: the need to regulate lenders. ${ }^{1}$ Many readers will also be familiar with the image of the gullible borrower in the clutches of an unscrupulous lender - a staple of theater and cinema. Given these concerns, we often see, especially in pre-modern times, attempts to curb the activities of lenders and protect borrowers. One such effort, the usury law, which places a ceiling on the interest rate, is quite well-known and understood. This paper analyzes a related institution which, in contrast, has received almost no scholarly attention: a ceiling on interest accumulation.

Ceilings on interest accumulation can be found in legal traditions around the world; they are part of Hindu law, Roman law, and Chinese law. Interestingly, in all these cases the ceiling is the same: interest accumulation cannot exceed the original principal, irrespective of how much time has elapsed. This rule is called Damdupat in Hindu law and Alterum Tantum in Roman law. It was also part of Chinese law for over a thousand years. In this paper we focus on the Hindu law case, which is best documented.

Though Damdupat is applied in parts of India even in the present-day, its origins can be traced back to the smrti, texts composed in the first few centuries of the Common Era. The smrti exposit the Dharmasastra, or the Hindu "science of righteousness." They have been described as "the authorities for application of law by any gathering with judicial powers" (Derrett 1963, p. 4) and have been routinely consulted by legal scholars and jurists in India in the colonial and post-colonial periods. Kane (1946), who is the leading authority on the Dharmasastra, cites as many as seven sources for Damdupat, including the famous Manusmrti. ${ }^{2}$

What rationale does the Dharmashastra offer for a rule like Damdupat? Kane suggests that it is best understood in conjunction with another Hindu rule, the "Pious

\footnotetext{
${ }^{1}$ See, for instance, for India, Hardiman (1996), Kumar (1968), and Deccan Riots Commission (1876). ${ }^{2}$ The Manusmrti is believed to have been composed during the first two centuries CE (Olivelle 2005, p. 37).
} 
Obligation," which obliged sons to pay their father's debts, with interest, even if they did not inherit property. ${ }^{3}$ A potential consequence of Pious Obligation is that if a man dies without repaying his debt, a huge amount of interest may have accumulated by the time his sons are in a position to pay. Kane (p. 423) argues that Damdupat was instituted because lenders might be tempted to exploit the exposure created by Pious Obligation: "[T]he sages who condemned the profession of usury and particularly waiting long for the increase of interest laid down that whatever the length of time during which the principal was at interest and whatever the rate of interest might have been, the creditor could recover by suit in a lump sum only double the amount lent." ${ }^{4}$ Thus, according to Kane, Damdupat protected the borrower from the lender's "rapacity." A similar rationale, in less colorful language, is offered by Derrett (1963 p.521). ${ }^{5}$

Kane's explanation raises a prior question: If Pious Obligation makes the borrower vulnerable in this manner, why does this norm exist? A straightforward explanation, based on standard credit models, seems available. In the environment we are considering (see below) the debtor faces limited liability. A borrower who cannot supply collateral will be subject to moral hazard and may therefore fail to obtain credit. Under Pious Obligation, the sons' incomes can serve as a collateral substitute. ${ }^{6}$ Thus,

\footnotetext{
${ }^{3}$ There was another clause as well, obliging grandsons to repay their grandfather's debt, though without interest, even if they did not inherit property.

${ }^{4}$ The use of the term "in a lump sum" in the description of Damdupat above requires some clarification. The law was implemented as follows. Suppose A has borrowed 100 rupees from B. The interest accumulates, and by the time B takes A to court, he is owed 300 rupees. Applying Damdupat, the court will award A only 200 rupees. But suppose A had previously paid interest of 100 rupees and now he owes a total of 200 rupees. If B takes A to court, he can receive the full amount of 200 . The borrower will eventually have repaid more than twice the principal, but Damdupat will not apply, because the borrower is not being asked to pay more than twice the outstanding principal at one time. There is also no restriction on capitalization of interest. Suppose that a few years prior to approaching the court the amount due was Rs. 150 (Rs. 100 of principal, and Rs. 50 in interest) and the lender and debtor had drawn up a new agreement converting the Rs. 150 into a fresh loan. Then the rule will apply to the figure Rs. 150 and the court will not award more than Rs. 300 .

${ }^{5}$ Derrett argues that Damdupat's "original function was to limit the liability of debtors' descendants in the male line whose responsibility to pay debts was not limited to assets, to pay debts with interest when the creditors of their ancestors might otherwise allow the amount of interest to accumulate indefinitely in a period when there was no efficient law of limitation of actions."

${ }^{6}$ This rationale has been endorsed by a scholar of the Dharmasastra (Banerjee 1971, p. 87). He also acknowledges the role of religious doctrine: a man who died with unpaid debts would be saddled with the burden of this sin and it was his sons' responsibility to ease this burden. He suggests that "sentimental and superstitious considerations reinforced secular considerations."
} 
Pious Obligation is not a puzzle for us. The more difficult question concerns Damdupat. Given Pious Obligation, can Damdupat promote social welfare? Under what conditions? To consider these questions, we work with a stylized model in which the borrower does not have collateral, but Pious Obligation achieves to perfection its objective of protecting the lender by making sure that the debtor's sons will fully repay his debt along with the interest. To keep the model simple we suppress the issue of borrowers' moral hazard and, taking our cue from Kane and Derrett, we look for a rationale for Damdupat as an institution that targets the behavior of lenders. For reasons explained in section two, we assume a monopolist lender. ${ }^{7}$

Our argument is as follows. Consider a world in which borrowers are not sure about their competence or project quality. In such a scenario, bidding by borrowers may not, by itself, lead to efficient allocation of capital. The lender can play a socially useful role by investigating borrower/project types. However, given Pious Obligation, the lender is always assured of repayment - even if the project fails, the sons will repay the principal and accumulated interest at a later date. This has two perverse effects: (a) given the repayment guarantee, the lender does not care if he lends to a "good" or a "bad" type, and (b) given this, under standard debt contracts, a lender who has chosen to be informed is unable to credibly communicate his knowledge of types to borrowers, and thereby cannot charge "good" borrowers higher rates of interest. Thus, the lender does not gain by investigating types and he will prefer to be "lazy." By putting a ceiling on interest accumulation, Damdupat eliminates (a). Now the lender has a reason to prefer to lend to "good" types, who will repay early, before the interest accumulation ceiling binds. Therefore, he can now credibly communicate his information and extract higher rates of interest from good types. Thus, Damdupat creates the incentive for the lender to investigate project/borrower quality. He is less likely to be "lazy" and capital will be allocated better. Our argument is in the spirit of Manove et al. (1999, 2001), whose work clarifies the general point that laws that weaken creditor rights can improve incentives for lenders.

We also present a variant of our model in which the borrower is not merely uninformed, but misinformed, i.e., he is excessively optimistic about his prospects. Such a borrower may accept contracts that require him to make large payments at a later date, if he is unable to repay early. The lender, who is able to extract large amounts of

\footnotetext{
${ }_{7}^{7}$ The implications of Damdupat in a competitive market are discussed in the concluding section.
} 
surplus from the "sucker," may have no incentive to investigate his type. By capping the payment that can be taken at a later date, Damdupat can weaken this perverse incentive.

Could the lender evade Damdupat by simply combining interest and principal into a fresh loan before the accumulation ceiling became binding? As we have described in footnote 4 the rule itself, in principle, did not preclude such a practice. However, such "interim" re-contracting is clearly not in the borrower's interest. The borrower would have to be forced into it in one of two ways: (a) by the threat of extracting immediate payment, causing severe hardship; or (b) via judicial process, with the courts forcing the borrower to recontract. Option (a) would be undermined by limited liability norms, which Indian judicial authorities seem to have typically upheld (see below). Option (b) would require collaboration of the judiciary in evasion of its own rules, which does not seem realistic. Indeed, as we later describe, Damdupat-like rules in China and in Roman law sometimes explicitly forbade the practice of rolling up outstanding principal and interest into a fresh loan.

In modeling Damdupat and Pious Obligation as a "package" we have been faithful to our textual sources. The reader should note, however, that there is a rationale for a rule like Damdupat even in the absence of Pious Obligation. One possibility, of course, is that a borrower's descendants may voluntarily take on his obligations, so that Pious Obligation may exist de facto even if not de jure. But more generally, the lender's incentive to be "lazy" may exist so long as the borrower has some other source of income that becomes available only at a later date. Consider, for instance, a loan at an interest rate of $25 \%$ which would compound to more than double in less than four years, well within the borrower's lifetime. A lender might think there is a realistic possibility that, despite the failure of the project for which he has borrowed the money, the borrower might be able to repay the full compounded amount at a later date. Damdupat will cap the potential repayment and thereby push the lender towards a "better" borrower who can repay earlier. Indeed, as we will discuss below, Damdupat was advocated and re-introduced in India during the colonial period even though Pious Obligation did not exist in the form described above.

Like many other real-world institutions (share-cropping, for instance), Damdupat can, in principle, serve more than one purpose. Perhaps the most obvious alternative explanation relates to risk; indeed, a host of institutions in poor economies have been 
explained by appeal to this consideration. A risk-averse agent may be unwilling to borrow unless there is a ceiling on his exposure; Damdupat can provide such a ceiling and raise welfare by encouraging borrowing and investment. This is easy to demonstrate in a simple model, which we provide in the appendix to this paper. However this explanation, though logical, is at odds with the rationale actually provided by policy-makers when Damdupat was advocated in India, at least in the colonial period. Damdupat was not introduced to encourage borrowing. It was proposed because policy-makers thought lenders had been given too much power to recover loans and were therefore lending too freely; this is consistent with our emphasis on lenders' incentives. We elaborate on this point in section five.

The rest of this paper is organized as follows. The next section provides some historical background and discusses the environment in which Pious Obligation and Damdupat operated. This discussion helps us motivate the assumptions in our formal model, which is presented in section three. Here we consider only simple debt contracts. In section four we consider the role of Damdupat in a world where a wider set of contracts is allowed. Section five discusses implementation of Damdupat in colonial and post-colonial India. Section six considers alternative plausible rationales for Damdupat. In section seven we consider similar rules in Roman and Chinese law. The final section summarizes and concludes.

\section{Historical Background}

Damdupat and Pious Obligation appear to have been in place over a long period of time in South Asia, in both rural and urban settings. It is likely that their impact varied across locations and time-periods, depending on market structure and legal environment, among other things. To model Damdupat and Pious Obligation we need a benchmark case which describes a common environment in which they operated. We focus on the state of Maharashtra, where the application of Damdupat, especially, is best documented. For much of its history the economy of Maharashtra has been predominantly rural and agricultural. We have fairly good descriptions of rural credit markets and contract enforcement mechanisms in pre-colonial times from various studies carried out at the onset of colonialism. These have been previously been used by Kranton and Swamy (1999), which we draw on for the description below. In this 
section we primarily focus on the pre-colonial and early colonial periods. Section five continues the discussion for later periods. ${ }^{8}$

The implementation of Damdupat in pre-colonial Maharashtra is described by numerous sources. In his study of the village of Lony, Coates (1823, p. 226) mentions a variant of Damdupat in which the lender can be awarded up to three times the original principal for grain loans:

Each debtor keeps a running account with his creditor, and takes receipts for sums he may from time to time pay, while the interest is brought against him till it equals the principal, where it legally ought to stop. "For money take double, and for grain or merchandize take treble," is the maxim that guides juries in adjusting these debts.

Lumsden (1819, p. 377) mentions that Damdupat was part of procedure for the more formal courts under the administration of the Peshwa. ${ }^{9}$ The implementation of Damdupat in Maharashtra is also documented by Steele (1868, 265-266), and the Deccan Riots Commission (1876, Memo. of Auckland Colvin, p. 30).

We also know that Pious Obligation was practiced. Arthur Steele, whom we quoted above, cites a report on the customs followed in Khandesh district: "A father's debts are to be paid, both principal and interest, whether the son receives the inheritance or not." Another official in Ahmednagar district wrote in 1851 (Hardiman 1996, p. 108):

It has always been the custom for the heirs of a man to become bound to discharge any debts he may have incurred. The ancient laws of the country considered the heirs of an individual answerable for all such debts he may have contracted, even though he left no property.

Thus, it appears that the Pious Obligation and Damdupat were being implemented in pre-colonial Maharashtra along the lines envisaged in the Dharmasastra. Below we discuss other features of the credit market; this discussion will inform the model we outline in the next section.

The professional trader-lender was arguably the dominant player in the credit market of rural Maharashtra, and continues to be important even to this day. Loans were provided for both consumption and production. Disputes regarding debts, as well

${ }^{8}$ British rule in the region now known as Maharashtra began with the defeat of the Marathas in 1818. The British withdrew in 1947, the year of Indian independence.

${ }^{9}$ The Peshwa was the de facto ruler in the later Maratha period. 
as other matters, were adjudicated by the village council, or Panchayat - a group of village elders. The Panchayat, however, did not retain a monopoly on coercive power; the lender needed to use "persuasion" to bring the borrower to adjudication, as well as for enforcement of the Panchayat's judgements. A common, and socially sanctioned, method was for the lender to post his servant to squat outside the house of the debtor (a practice known as "dharna") thereby publicly shaming him. The debtor was was also required to pay for his tormentor's daily nourishment! Kranton and Swamy argue that the lender's need to rely on private resources for enforcement tended to fragment the credit market. Lenders could operate only in a small geographic area where they could enforce contracts. The relatively small number of lenders in (say) a village might then have the opportunity to collude, and exercise market power. Collusion would also be facilitated by lenders' common caste or ethnic background. In modeling this environment we simplify, and assume a monopolist lender. This framework, in which lenders have market power due to enforcement and information advantages, is commonly used in models of informal credit markets in the developing world. ${ }^{10}$

Accounts of this period also suggest another feature of the legal environment: the debtor faced limited liability. The members of the Panchayat, who belonged to the village, were unlikely to pass judgements that would completely ruin the debtor. Indeed, in his (1826) study of the customs and rules of "Hindoo castes" in our region Arthur Steele reports that Panchayats awarded decrees "according to the debtor's circumstances." Consistent with this, we assume, as do other models of credit markets in developing countries, that repayment is enforced subject to a floor on the debtor's remaining income.

It is also plausible to assume, as we do below, that in this environment the borrower cannot engage in "strategic default," i.e., he cannot refuse to repay if he has funds on hand. In such a circumstance the lender would use the enforcement methods described above to recover his money. Given limited geographic mobility, the option of the "running away with the money" is not available to the debtor.

Based on this description, we now present a stylized model of the credit market, to consider the rationale for Damdupat.

\footnotetext{
${ }^{10}$ See, for instance, chapter 13 of Kaushik Basu's (1997) Analytical Development Economics.
} 


\section{MODEL}

Consider a two period world. There is a monopolist lender and a potential borrower. At the beginning of period 1, the borrower has a project that requires 1 unit of capital. The project lasts one period and can be either good or bad. If good (bad), the project gives gross return $R(0)$. The borrower does not know if he is endowed with a good or a bad project. Let $p \in[0,1]$ denote the ex-ante probability that the borrower has a good project. We assume that $p$ is common knowledge between the borrower and the lender. In each period there is a saving technology (available to both borrower as well as the lender) which yields a gross return $\Delta(\geq 1)$. It is assumed that the borrower does not have any other income/wealth in periods 1 and 2. However, he has wealth $S$ at the end of the second period (think of $S$ as the sons' earnings). Throughout the paper we make the following assumptions.

Assumption 1. $R>\Delta$

Assumption 2. $S>\Delta^{2}$

In words, if the project is known to be good then it is socially optimal to finance it. The second assumption was described in the introduction: there exists a simple debt contract with some interest rate greater than $\Delta$, for which Pious Obligation guarantees full repayment with interest.

It is assumed that the lender has expertise in evaluating project quality. In particular, the lender can perfectly learn the project quality by incurring a cost $c>0 .{ }^{11}$ When is it socially optimal to acquire information? Suppose that returns are evaluated at the end of the second period. If the project quality is known to be good, which happens with probability $p$, then the return is $R \Delta$, otherwise (with probability $1-p)$ the return is $\Delta^{2}$. Therefore, if the lender decides to obtain full information the ex ante expected return is

$$
p R \Delta+(1-p) \Delta^{2}
$$

If the lender decides not to obtain full information, then he will finance the project if and only if the expected return form so doing, $p R \Delta$, is greater than the return from saving, $\Delta^{2}$. Therefore social return in the uninformed case is $\max \left\{\Delta^{2}, p R \Delta\right\}$. Note

\footnotetext{
${ }^{11}$ Some readers may be skeptical that the lender can acquire information that is unavailable to the borrower. Manove et al. (2001) point out, however, that a similar premise underlies the academic refereeing process!
} 
that because $R>\Delta$, it must be true that the gross social return in the informed case exceeds the social return in the uninformed case. Hence, it is socially optimal to acquire information if

$$
p R \Delta+(1-p) \Delta^{2}-c>\max \left\{\Delta^{2}, p R \Delta\right\}
$$

3.1. Lending under Standard Debt Contracts. Suppose that the courts implement only standard debt contracts. A standard debt contract is fully described by an interest rate $r$ per period. ${ }^{12}$ Under such a contract the amount owed by the borrower compounds in every period at a constant rate $r$.

As mentioned earlier, we make two important assumptions about contract enforcement. First, the borrower is protected by limited liability - if the lender sues the borrower for recovery, the borrower is liable only up to his resources above his basic means for survival. ${ }^{13}$ This assumption implies that the borrower cannot be "held-up" in the interim period and be forced to sign a fresh contract at a high interest rate. Second, there can be no strategic default - if the borrower has resources to repay, he will be forced to repay.

The interaction between the lender and a borrower is modeled as follows.

(1) Nature chooses project quality which is not observed by the borrower. The project is good (denoted by $g$ ) with probability $p$ and bad (denoted by $b$ ) with probability $1-p$.

(2) The lender decides whether or not to find out project quality by incurring cost $c>0$. (The borrower observes the lender's decision.) Formally, let $s \in\{U, I\}$ denote the action chosen by the lender where $I$ denotes the decision to be informed and $U$ denotes the decision to be uninformed.

(3) The lender decides whether to finance the project or to save. If he decides to finance the project he makes a 'take-it-or-leave-it' offer to the borrower at interest rate $r$. Formally, an uninformed lender's strategy can be described as $\alpha_{U} \in \Re_{+} \cup\{$ save $\}$, whereas an informed lender's strategy can be described as $\alpha_{I}:\{g, b\} \rightarrow \Re_{+} \cup\{$ save $\}$.

\footnotetext{
12 Throughout the paper the term interest rate is used to mean the gross interest rate.

${ }^{13}$ For convenience we normalize the minimum amount that the borrower needs for his survival to 0 .
} 
(4) The borrower, if offered a debt contract, decides whether or not to accept the offer. Formally, a borrower's strategy can be described as $\beta:\{U, I\} \times \Re_{+} \rightarrow$ $\{$ accept, reject $\}$. If the borrower rejects the contract, the lender saves.

We shall employ the notion of the Weak Perfect Bayesian Equilibrium (WPBE) as the solution concept for analyzing the "lending game" described above. Formally, the equilibrium is a collection of strategies $-\left(s, \alpha_{U}, \alpha_{I}\right)$ for the lender, $\beta$ for the borrower; and a belief system for the borrower $\mu:\{U, I\} \times \Re_{+} \rightarrow[0,1]$ where $\mu$ denotes the borrower's subjective probability that he has a good project, such that:

(1) The borrower's strategy $\beta$ is (sequentially) rational under $\mu$.

(2) The belief system $\mu$ is derived from the lender's strategy through Bayes' rule at every information set reached with positive probability under the lender's strategy. ${ }^{14}$

To solve for the equilibrium of the game we shall separately consider its two subgames: one following the decision of the lender to stay uninformed (i.e. $s=U$ ) and the one following the lender's decision to become informed (i.e. $s=I$ ).

3.1.1. Uninformed Lender. Consider first the case where the lender is uninformed. Suppose the lender offers a contract at interest $r$. As the lender is uninformed, $\mu(r)=p$ under any consistent belief system. Under such beliefs the borrower's net expected payoff from accepting the contract is

$$
p(R-r) \Delta-(1-p) \min \left\{r^{2}, S\right\}
$$

The borrower will accept the contract only if the above payoff is non-negative, i.e., if

$$
\operatorname{pr} \Delta+(1-p) \min \left\{r^{2}, S\right\} \leq p R \Delta
$$

Clearly, if $p R \Delta \leq \Delta^{2}$, i.e., $p R \leq \Delta$, then the lender will prefer to not lend. ${ }^{15}$ If, on the other hand, $p R>\Delta$, then the lender will lend at the interest rate $\widehat{r}$ such that

$$
p \widehat{r} \Delta+(1-p) \min \left\{\widehat{r}^{2}, S\right\}=p R \Delta
$$

Hence we have the following lemma:

\footnotetext{
${ }^{14}$ See, Definition 9.C.3 in Microeconomic Theory by Mas-Colell, Whinston and Green (1995, p. 285). ${ }^{15}$ The lender will either choose to save or will offer a contract that will be rejected by the borrower and the lender will end up saving. If we assume there is a small cost to offering a contract, then there will be a unique equilibrium of the lending game in which the uninformed lender chooses to save.
} 
Lemma 1. In any equilibrium of the lending game under standard debt contract, the uninformed lender chooses to save if $p R \leq \Delta$, and chooses to lend at interest $\widehat{r}$ as given in equation (3) if $p R>\Delta$.

The intuition behind this result is straightforward - since the lender is uninformed, his action conveys no information to the borrower. Hence, the borrower is willing to pay at most $p R \Delta$ for the project. The lender will (will not) lend if his payoff from lending is greater (less) than that from saving.

3.1.2. Informed Lender. Now suppose that the lender is informed. Can he offer a feasible contract that earns him more than the payoff he would earn if he were uninformed? We shall show that this is not possible.

At any interest rate $r>\Delta$ he makes $r \Delta>\Delta^{2}$ by lending to the good type and makes $\min \left\{r^{2}, S\right\}>\Delta^{2}$ lending to the bad type. Hence, the lender cannot credibly lend only to the good types at such an interest rate. Hence, in any sequential equilibrium of the lending game, the borrower who is offered a debt contract $r>\Delta$ must infer that he is the "average" type, i.e., the lender cannot credibly offer a separating contract. Hence, we have:

Lemma 2. Under the standard debt contract, in any sequential equilibrium, an informed lender saves if $p R<\Delta$ and he lends to both types at $\hat{r}$ as given in equation (3) if $p R>\Delta$.

The intuition behind the above result can be obtained by doing the following thought experiment. Suppose I am a borrower who is offered a contract $r>\Delta$ by an informed lender. Would the lender have lent to me at this rate if I were bad? The answer is yes, since the lender makes $\min \left\{r^{2}, S\right\}>\Delta^{2}$ by lending to a bad type. Would the lender have lent to me at this rate if I were good? Again the answer is yes since the lender makes $r \Delta>\Delta^{2}$ by lending to a good type. Hence, I cannot infer anything about my type from the fact that the lender offered me a contract $r$. Hence, I must conclude that I must be the "average" type.

From lemmas 1 and 2, it follows that there is no incentive to acquire information under the standard debt contract.

Proposition 1. Under the standard debt contract, the lender earns the same payoff whether he is informed or uninformed. Hence, for any $c>0$, he strictly prefers to stay uninformed. 
3.2. Standard Debt Contracts with a Damdupat Clause. Now suppose that Damdupat is in place. This rule requires that the lender shall not be able to recover more than twice the original amount lent. In our context, this rule means that the lender cannot collect more than 2 (since the initial investment is 1 ). We shall now analyze the implications of this restriction for the lending game. The structure of the game is same as before. In order to focus on the case of interest we make the following assumption

Assumption 3. $R \leq 2<R^{2}$

This assumption implies that if the project is good, then it can be financed without running into the Damdupat constraint, and if the project fails, the interest accumulated over two periods exceeds the Damdupat limit. Again, suppose that the lender is uninformed. The net expected payoff to the borrower under interest $r$ is now

$$
p(R-r) \Delta+(1-p)(-2)
$$

The highest rate of interest that the borrower is willing to accept is given by $\widetilde{r}$, where

$$
p \widetilde{r} \Delta+(1-p) 2=p R \Delta
$$

The lender will lend at such an interest rate if $p R>\Delta$, otherwise he will save. To sum up:

Lemma 3. Under a debt contract with Damdupat, the uninformed lender chooses to save and earns $\Delta^{2}$ if $p R \leq \Delta$, and he lends at interest rate $\widetilde{r}$ as given in equation (4) if $p R>\Delta$.

Now consider the behavior of an informed lender. Given that Damdupat is in place, the informed lender's payoff from lending to a bad type at rate $r$ is $\min \left\{r^{2}, 2\right\}$. Also, at any $r \leq R$, his payoff from lending to a good type is $r \Delta$. If $\Delta^{2} \geq 2$, then at any interest rate, the lender is (weakly) better off saving than lending to the bad type. Hence, by choosing to lend the lender will be able to credibly signal to the borrower that he is good.

Suppose that the players' strategies and beliefs are as follows. a) The lender uses the strategy: lend to good types at $R$ and do not lend to bad types. b) The borrower's beliefs are: the project is of type $g$ if the lender offers a loan and it is of type $b$ otherwise. c) The borrower's strategy is: accept the contract at any interest rate $r \leq R$. 
It is easy to verify that the above strategies and beliefs constitute a WPBE. Note that the lender's expected payoff under his strategy is

$$
p R \Delta+(1-p) \Delta^{2}
$$

which is better than saving since $R>\Delta$. Is this strategy optimal? Suppose that the lender deviates and lends at $R$ to a bad type as well. In this case, the loans made to bad types will not pay off in the first period and will yield only 2 in the second period due to Damdupat. Hence, he will earn

$$
p R \Delta+(1-p) 2
$$

This deviation will not be profitable if $\Delta^{2} \geq 2$. It is also easy to see that the borrower's beliefs are consistent with the lender's strategy and his strategy is optimal under those beliefs.

On the other hand, if $\Delta^{2}<2$, the lender will never be able to credibly offer a separating contract to the good types. Hence we have:

Lemma 4. If $\Delta^{2} \geq 2$, then there exists an equilibrium of the lending game under Damdupat in which the informed lender lends only to the high types and charges them $R$. If $\Delta^{2}<2$, then the lender's strategy is same as described in lemma 3.

Note that if $\Delta^{2} \geq 2$, then Damdupat, by capping the amount that the lender can earn in case of default, enables the lender to credibly signal to the borrowers their true types. This in turn enables him to charge the good borrowers a high rate of interest. Now when is the information worth acquiring? Note that the payoff to being informed is $p R \Delta+(1-p) \Delta^{2}$ while that to being uninformed is $\Delta^{2}$ if $p R \leq \Delta$ and $p R \Delta$ if $p R>\Delta$. Hence, the lender will choose to acquire information under Damdupat if

$$
p R \Delta+(1-p) \Delta^{2}-c>\max \left\{\Delta^{2}, p R \Delta\right\}
$$

Note that the above equation is identical to (1). Hence, if $\Delta^{2}>2$, in our model, Damdupat can implement the first best.

Proposition 2. Suppose $\Delta^{2} \geq 2$, then there exists an equilibrium of the lending game under Damdupat such that the lender chooses to acquire information and lends only to the good types. Moreover, the equilibrium outcome corresponds to the first best.

In fact, from the reasoning used above, we can state a more general result about Damdupat-like institutions. Consider a generalization of Damdupat to Damdupat ${ }_{k}$ 
which stipulates that the amount collected on a 1 unit of debt cannot exceed $k$. As long as $k \leq \Delta^{2}$, the informed lender can credibly signal to the borrowers their types. Hence, he can charge $R$ to the good borrowers and save if the borrower is bad. Thus, the lender has the incentive to acquire information about the borrower, provided that the cost is not very high.

\section{General Contracts and Overoptimistic Borrowers}

In the preceding analysis we restricted our attention to simple debt contracts. However, it is conceivable that in some environments courts are willing to enforce more general contracts of the form "pay $t_{1}$ at the end of period one; if you are unable to do so pay $t_{2}$ at the end of period 2." Suppose, for instance, that the lender chooses to charge a low interest rate and a hefty penalty for late repayment. To do so, he will set a low $t_{1}$ and a high $t_{2}$. Alternatively, a lender who wants to credibly signal type to a "good" borrower might offer a Damdupat-like contract: pay $R$ in period 1; if you are unable to do so, pay 0 in period 2. Will Damdupat still serve a purpose in such an environment? Under the assumptions of the previous section, it will not: as argued above, the lender will have an incentive to privately offer a Damdupat-like contract thereby making the external imposition of Damdupat redundant. However, we argue in this section, Damdupat will still play a useful role if the borrowers are not merely uninformed (as in the preceding section) but misinformed. In particular, if the borrowers are overly optimistic, i.e., they overestimate the probability of success, they may accept contracts with low interest rates and hefty penalties for late payment from an uninformed lender. The lender may make more money by remaining uninformed and offering such a contract. An externally imposed Damdupat clause can limit the penalties for late payment and weaken this perverse incentive for the lender.

Let $x$ denote the subjective probability attached by a borrower to the event that his project is "good." Let $x>p$, i.e., the borrower overestimates the probability that he has a good project. It is assumed that the lender knows $p$ and $x$. Regarding the returns from the project and the outside option, assume $1<\Delta<R$ and $\Delta^{2}>2$.

4.1. Optimal Contract by an Uninformed Lender. The contract offered by an uninformed lender can be represented by a pair $\left(t_{1}, t_{2}\right)$ with the interpretation "pay $t_{1}$ at the end of period 1 ; if you are unable to pay that, pay $t_{2}$ at the end of period 
2." The perceived expected payoff to the borrower from accepting this contract is

$$
x\left(R-t_{1}\right) \Delta+(1-x)\left(-t_{2}\right)
$$

The borrower will accept contract $\left(t_{1}, t_{2}\right)$ if the above perceived expected payoff is non-negative, i.e.

$$
x t_{1} \Delta+(1-x) t_{2} \leq x R \Delta
$$

If the borrower accepts the contract, the lender's expected payoff is

$$
p t_{1} \Delta+(1-p) t_{2}
$$

To find the profit maximizing feasible contract from the uninformed lender's point of view, we solve the following problem:

$$
\begin{array}{cl}
\text { Maximize } & p t_{1} \Delta+(1-p) t_{2} \\
\text { subject to } & x t_{1} \Delta+(1-x) t_{2} \leq x R \Delta \\
& t_{1} \geq 0, t_{2} \geq 0
\end{array}
$$

It is easy to see that the first constraint must be binding. Solving for $t_{1}$ in terms of $t_{2}$, we can rewrite the problem as:

$$
\begin{array}{ll}
\text { Maximize } & p \Delta\left(R-\frac{1-x}{x \Delta} t_{2}\right)+(1-p) t_{2} \\
\text { subject to } & t_{1} \geq 0, t_{2} \geq 0
\end{array}
$$

Note that for $x>p$, the objective function is strictly increasing in $t_{2}$. Hence, the lender would like to set $t_{2}$ as large as possible. So, he will set $t_{1}$ just large enough to induce a default ${ }^{16}$ and would like to set a very high $t_{2}$. Hence, the optimal contract from the lender's point of view is $t_{1}^{*}=0, t_{2}^{*}=\frac{x}{1-x} R \Delta^{17}$. The lender's payoff from such contract is

$$
\Pi_{U}^{*}=(1-p) \frac{x}{1-x} R \Delta
$$

Finally, we need to verify that the lender is better off lending rather than exercising his outside option, i.e., the above number is greater than $\Delta^{2}$.

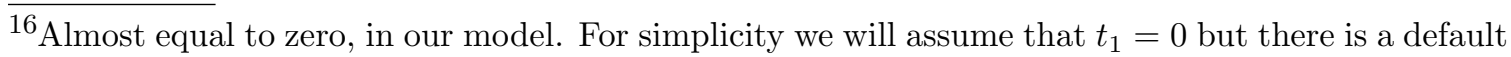
in period 1 if the project fails.

${ }^{17}$ This is assuming $S$ to be sufficiently large. While this assumption is not critical to our result, it makes the exposition simple.
} 


\subsection{Optimal Contract under the Damdupat Constraint by an Uninformed}

Lender. Under Damdupat, the maximization problem solved by an uninformed lender is given by:

$$
\begin{array}{cl}
\text { Maximize } & p t_{1} \Delta+(1-p) t_{2} \\
\text { subject to } & x t_{1} \Delta+(1-x) t_{2} \leq x R \Delta \\
& t_{1} \geq 0, t_{2} \geq 0 \text { and } t_{2} \leq 2
\end{array}
$$

It is easy to see that the Damdupat constraint will be binding in equilibrium as long as $t_{2}^{*}>2$. Hence, under Damdupat we have, $t_{2}^{\mathrm{DD}}=2$ and $t_{1}^{\mathrm{DD}}=R-\frac{1-x}{x \Delta} 2$. The expected payoff of the uninformed lender will be

$$
\Pi_{U}^{\mathrm{DD}}=p\left(R-\frac{1-x}{x \Delta} 2\right) \Delta+(1-p) 2
$$

4.3. Optimal Separating Contract by an Informed Lender. In any WPBE in which the informed lender offers two separate contracts to the two types, the borrower must be rationally able to infer his type. Since the good type is willing to pay up to $R$ and the bad type will not accept a contract except at zero interest, the highest attainable payoff under a separating contract is $p R \Delta+(1-p) \Delta^{2}$. Note that any separating contract involves the good type being offered a high payment in period one and a low payment in period two. Such contracts (for instance $(R, 0)$ ) do not run into the Damdupat constraint. Therefore, even after the imposition of Damdupat, the expected payoff from the best separating contract remains the same as given by the above equation. Hence we have:

$$
\Pi_{I}^{*}=p R \Delta+(1-p) \Delta^{2}=\Pi_{I}^{\mathrm{DD}}
$$

4.4. Comparing Payoffs to acquiring Information. By comparing equations $(6),(7)$ and (8), we are able to see when it is in the interest of the lender to get informed. Note that the lender will not get informed without Damdupat but will get informed under Damdupat if:

$$
\begin{aligned}
\Pi_{U}^{D D}<\Pi_{I}^{D D} & \text { i.e. } p\left(R-\frac{1-x}{x \Delta} 2\right) \Delta+(1-p) 2<p R \Delta+(1-p) \Delta^{2} \\
\Pi_{I}^{*}<\Pi_{U}^{*} & \text { i.e. } p R \Delta+(1-p) \Delta^{2}<(1-p) \frac{x}{1-x} R \Delta
\end{aligned}
$$


Observe that equation (9) always holds since $\Delta^{2}>2$. Equation (10) will hold so long as $x$ is sufficiently large. Hence, we obtain the following result:

Proposition 3. If the borrower is sufficiently overoptimistic, i.e., if $x>\bar{x}$, where $\bar{x}$ satisfies equation (10) with equality, then the lender will be better off not acquiring information.

The intuition for this result is as follows: The informed lender is able to maximize the total surplus and reduce the borrower to his outside option (zero net earnings). The uninformed lender does not maximize the total surplus but the overoptimistic borrower earns a negative expected return. If the borrower is sufficiently overoptimistic, the lender will do better by getting a larger piece of a smaller pie.

The following numerical example may help clarify our result. Let $p=1 / 2, x=2 / 3$, $\Delta=1.5$ and $R=1.7$. Hence we have,

$$
\begin{aligned}
& p\left(R-\frac{1-x}{x \Delta} 2\right) \Delta+(1-p) 2=2.1 \\
& p R \Delta+(1-p) \Delta^{2}=2.40 \\
& (1-p) \frac{x}{1-x} R \Delta=2.55
\end{aligned}
$$

As seen in this example, if any type of contracts were feasible, the lender would be better off staying uninformed as $2.55>2.40$. However, with the imposition of Damdupat there exists an equilibrium in which the lender acquires information as $2.1<2.40$.

\section{Damdupat in Colonial and Post-Colonial India}

We have previously argued that Pious Obligation and Damdupat, as described in the classical texts, were implemented in pre-colonial Maharashtra. The same cannot be said for the colonial and post-colonial periods. In its first phase, British-Indian law did not recognize Damdupat. And regarding Pious Obligation, Hardiman (1996, p. 108) writes of the same period: "Under British law no person who had reached the age of majority could be held responsible in a court of law for the debts of an ancestor." However, according to Kane (1946, p. 445) the law with respect to Pious Obligation was clarified in the 1860's. A judge in a case filed in the Bombay High Court ruled that a grandson was liable to pay his grandfather's debt without interest even if he had no inherited property (see footnote 3 ). This was subsequently considered unfair, 
and in 1866 the Hindu Heirs' Relief Act was passed whereby sons and grandsons were liable only to the extent of property inherited. From this point onwards, from our perspective, Pious Obligation lost its "bite," i.e., it could no longer serve its purpose as a collateral substitute. Pious Obligation continues to be part of present-day law, in this curtailed form.

If we take the variable $S$ in our model as representing the sons' Pious Obligation to pay out of their own earnings, its weakening as described above will take away the rationale for Damdupat: " $S$ " has been reduced to zero, and Damdupat will never bind. However, as we have argued earlier, $S$ does not have to be the sons' earnings it can be any other later source of income for the borrower. So, despite the change in Pious Obligation, there was still a potential role for Damdupat. British administrators had knowledge of this rule, and a dramatic event, described below, precipitated its introduction into law in the Bombay Deccan. ${ }^{18}$

After the onset of colonial rule, the British introduced three important innovations that greatly facilitated loan recovery by lenders. The first was a legal system in which both the delivery of judgements (such as as foreclosures) as well as their execution was expedited. For instance, the civil courts introduced by the British often delivered ex-parte decisions, i.e., rulings in the absence of the defendant. The second was the formalization and individualization of land rights, which made it much easier to use land as collateral. Third, in British law (in the Bombay Deccan) land could be seized in lieu of loan repayment even if it had not been explicitly pledged as collateral. As a result, lending activity increased dramatically, as did the level of debt (Kranton and Swamy 1999). There was a great deal of concern among British officialdom that peasants were becoming too heavily indebted, that the rate of foreclosures was too high, and that lenders had been given too much power. These concerns came to a head when peasants in two districts, Poona and Ahmednagar, rioted in 1875, attacking moneylenders and confiscating the bonds that recorded their debt. The British worried that, should such unrest spread, their rule might be threatened. The Deccan Riots Commission was asked to investigate the causes of the riots and recommend policy measures that might be introduced. The Commission proposed introduction of Damdupat as part of a package of policy changes.

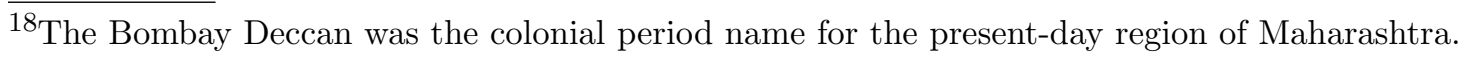


Damdupat had been proposed even earlier, in 1852, by Sir George Wingate, a senior official. He argued, as did many other British administrators, that British legal innovations were excessively biased in favor of the lender and "the facilities which the law affords for the realization of debt have expanded credit to a most hurtful extent..." (Deccan Riots Commission 1876, p. 39). He also wrote (Hope 1879, p. 27):

It remains to be shown how it is that the creditor in our [British] Provinces has acquired a degree of power over his debtor which is wholly unknown in Native States. This power, it is clear to me, has been conferred by our laws which enable the creditor to obtain a decree against a debtor for whatever may be written in his bond, and enforcement of that decree by attachment and sale of whatever property, moveable or immoveable, his debtor may possess or acquire ... The first remedy I suggest is as follows ... The enactment of a law to permit the Court to decree in all cases, on equitable consideration, whatever rate of interest it may deem proper; but that in no case shall the total amount of interest exceed the principal.

One of the respondents to the Deccan Riots Commission, a Sessions Judge, proposed an even tougher law than Damdupat, further reducing the amount a court could award, and recommending extension of the law beyond the Hindu community. In response to the commission's findings the Deccan Agriculturists' Relief Act was introduced in 1879. It contained numerous provisions that were aimed at protecting the peasant, such as better documentation and registration of debts, and a ban on seizure of land unless explicitly pledged as collateral. Damdupat was introduced as part of this package and is still on the law books in Maharashtra (Joshi 2005, Gandhi 2003, p. 143).

Damdupat was also introduced in the colonial period in other regions such as Santhal Parganas, under similar circumstances. The Santhals are a tribal community in eastern India. Following legal changes similar to those described above, extensive foreclosure by immigrant moneylenders had led them to rebel in 1855. Various attempts were then made to "protect" the Santhals including restrictions on land transfers. In his famous report on survey and settlement operations in the Santhal Parganas ${ }^{19}$ Mcpherson (1909, p. 40) reports that despite this, by the early 1870's the Santhals were "crushed by the extortionate interest allowed on debts." In response

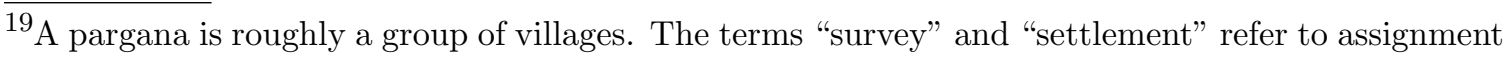
of land rights and taxes.
} 
to new "unrest" not only Damdupat, but also a usury law and a ban on compound interest (both of which measures we discuss below) were introduced in 1872:

\begin{abstract}
A full enquiry into the grievances of raiyats [farmers] was made and the eventual result was the passing of Regulation III of 1872, which may be described as the Magna Charta of the Sonthal Parganas. The new Regulation re-affirmed the exemption of the district from the operation of all Regulations and Acts not specially extended to it. It limited interest on debt to 24 per cent per annum and to an ultimate amount not exceeding the principal, and it excluded compound interest.
\end{abstract}

Arguments similar to Wingate's were presented by McAlpin (1909, p. 71), urging extension of the rules applied in the Santhal Parganas to four other districts with Santhal populations (Birbhum, Bankura, Midnapore, and North Balasore). Like Wingate, McAlpin wants to curtail lending. He acknowledges that his proposals "interfere considerably with credit." However, he argues, no doubt paternalistically, that "it is credit which is the ruin of the aborigine." Recommending a combination of usury law and Damdupat, he proposes (p. 86) that "the total interest decreed on any loan or debt shall never exceed one-fourth of the principal sum, if the period be not more than one year, and shall not in any other case exceed the principal of the original debt or loan."

Damdupat continues to be on the law books in the Santhal Parganas, and also in Gujarat, and Kolkata (Gandhi 2003, p. 143).

\title{
6. Alternative Explanations
}

We have argued earlier that institutions like Damdupat can, in principle, serve more than one function. Below we consider some alternative roles for Damdupat.

6.1. Damdupat as insurance to the borrower. Consider a world where there is no uncertainty regarding the borrower types, but each borrower faces a risky project with a positive net expected return. Under a standard debt contract, the following scenarios emerge: if the project succeeds, the debt is settled at the end of the first period; if it fails, debt accumulates at compound interest till it is repaid at some future date. A sufficiently risk averse borrower might deem this risk to be too high to undertake the project at any rate of interest that is above the lender's outside option. In this world, imposing Damdupat will provide some protection to the borrower 
against the downside risk and may thereby induce him to undertake the project. This argument is formalized in the appendix to this paper.

At the level of theory this explanation nicely complements ours: Damdupat could provide insurance to borrowers and provide incentives to lenders. However, as our discussion above indicates, the insurance-based explanation is not consistent with the intentions of policy-makers, at least during the colonial period. Damdupat was not introduced to encourage borrowing by the peasantry; it was introduced when it was felt that lenders were dispensing credit too freely, because they received too much protection from the law. Damdupat was a way of curtailing the powers of loan recovery of the lender.

6.2. Damdupat as a bankruptcy law. A bankruptcy law is typically designed to ensure that the borrower and his family have a certain minimum standard of living in case of default. Such protection may be afforded to the borrower on humanitarian grounds or on efficiency grounds - say to give him a fresh start or to encourage him to undertake a risky project in the first place (see the discussion above). Damdupat differs from bankruptcy law in that it puts an upper limit on the amount that can be recovered by the lender whereas a bankruptcy law puts a lower limit on what the borrower must be left with. These are two different objectives and there may be a rationale for imposing Damdupat even after a bankruptcy law is in place. For instance, assume that the borrower (or his son) must be left with a minimum amount of income, $\bar{m}>0$, in period 2. As long as $S-\bar{m}>\Delta^{2}$, the lender will still have an incentive to lend to a bad type. Hence, there will be an efficiency rationale for imposing Damdupat over and above a bankruptcy law.

6.3. Damdupat as a usury law. Damdupat shares a certain superficial similarity with a usury law - both try to put a limit on the amount that the lender can charge the borrower. However, a usury law limits the rate of interest and not the total amount of recoverable interest. It is clear, in the context of our model, that a usury law will not create differential incentives for lending to good and bad types of borrowers - any usury law that restricts the rate of interest at $\bar{r} \geq \Delta$ will not affect the lender's incentive to lend to the bad types. If, on the other hand, $\bar{r}<\Delta$, no lending will take place. In either case, there will be no information acquisition. In fact, a combination of usury law (as long as it is not too restrictive) and Damdupat 
can lead to efficient resource allocation while transferring some surplus to the borrower. Indeed, in India (as seen above) as well as in Roman and Chinese law (which we discuss in the following section), usury laws have coexisted with Damdupat-like restrictions on interest accumulation.

6.4. Damdupat as a solution to lender opportunism. It is conceivable that in traditional Indian society the lender and the borrower did not have equal access to the courts and this created a potential for the lender to extort money from the borrower. One problem reported by scholars is that the lender would refuse to acknowledge interim payments by the borrower. In particular, if the lender has managed to lend to the borrower at a high interest rate, then the lender has an incentive to receive his money later rather than sooner. He may thus hold up the borrower by refusing to acknowledge payment. Damdupat, by capping the amount of accumulated interest, will put the onus of collecting money on the lender. While this is a potential explanation for Damdupat, there were other institutional arrangements to address this problem. For instance, the state would appoint an official to whom the borrower could make payments in the event the lender refused to accept it. We see references to this in the classical texts as well as in documents from the British period.

6.5. Damdupat as a solution to the lender's moral hazard problem. Yet another rationale for Damdupat may emerge when the lender has a potential role to play in the project. For instance if the lender is the landlord or the merchant and the borrower the local farmer, one can think of the lender providing inputs (e.g. investment in land improvement, provision of storage facility for grains) which are not verifiable at the time when loan contract is written. If the lender is assured of repayment irrespective of the project's outcome, he will shirk in the provision of these inputs. By making the lender's payoff contingent on project success, Damdupat solves the moral hazard problem of the lender. This explanation, though plausible, does not account for across-the-board implementation of Damdupat even in settings where lenders did not participate in projects. Indeed, specialist trading-lending communities in India, like the Marwaris, do not seem to have directly involved themselves in their borrowers' economic activities. 


\section{Other Credit Rules}

A rule very much like Damdupat, known as Alterum Tantum ("as much more") was part of Roman law. Zimmerman (1996, p. 169) reports that in Roman law of the classical period lenders did not have the right to interest arrears in excess of the amount borrowed. ${ }^{20}$ To support this claim, he quotes the dictum from an important jurist, Domitius Ulpianus: "Supra Duplem Autem Usurae." We also find the rule of Alterum Tantum in the famous Institutes of Justinian, published in 533 CE. Justinian, who became the emperor of the Byzantine or Eastern Roman Empire in 527 $\mathrm{CE}$, initiated a vast project to compile and clarify existing Roman law. The project included a collection of the works of jurists (Ulpianus was a prominent inclusion) produced mostly over the period $100 \mathrm{BCE}$ to $300 \mathrm{CE}$, which was known as the Digest (Tellegen-Couperus 1993, p. 142). Because the Digest was too voluminous, a textbook known as the Institutes was published. Sohm (1892 p. 298) reports that according to the Institutes, "Arrears of interest can only be recovered to the extent of capital debt, i.e., not ultra alterum tantum."

The rule of Alterum Tantum appears to have subsequently found its way into law in Western Europe. Roman law was not extensively studied from the sixth to the eleventh centuries, but beginning in the late eleventh century, there was renewed interest in Justinian's Digest, a development of great importance for the subsequent legal evolution. ${ }^{21}$ Roman law remained extremely influential henceforth, despite the role of regional customs and canonical law, developed in the Christian church. ${ }^{22}$ To the extent that in medieval Europe the Christian church's prohibition on taking any interest at all was obeyed Alterum Tantum would have been redundant. But usury laws were steadily weakened after the medieval period so that Alterum Tantum would have become relevant again. Upton (1998, p. 115), describes a controversy in Sweden in the late $17^{\text {th }}$ century wherein the state wanted to invoke Alterum Tantum in regard to its public debt. He refers to Alterum Tantum as a "medieval rule for the relief

\footnotetext{
${ }^{20}$ The first two centuries of the Common Era are usually considered the classical period of Roman law.

${ }^{21}$ Stein $(1999$, p. 43) argues that "it is difficult overrate the significance of the rediscovery of the Digest."

${ }^{22}$ According to Stein, Goethe used the analogy of a duck to describe the role of Roman law: it was sometimes below the water (less prominent) and sometimes above the water (more prominent), but "always there."
} 
of poor debtors," but its form is slightly different from the description above: once the interest paid reached the amount of the principal, subsequent repayment went towards the principal. ${ }^{23}$ Upton reports that the application of Alterum Tantum was endorsed by the clergy, who argued that it was consistent with scripture. Supporters also argued that it had some foundation in the Land Law, a code of national laws that was formalized in the $14^{\text {th }}$ century. Finally, it is interesting to note that Alterum Tantum has even been invoked in the context of lending from one country to another. Lauterpecht (1927, p. 270) reports on an international dispute in the beginning of the second half of the $19^{\text {th }}$ century, which was adjudicated by Senate of Hamburg, an international tribunal. The creditor (Britain) was owed interest substantially in excess of the principal. The tribunal adopted Alterum Tantum, arguing that "Roman law is the only one applicable in such a case."

A similar rule was observed in China. Surveying civil economic legislation in China from the Tang dynasty (618 CE - 907 CE) to the Qing dynasty (1644 CE-1911 CE), Junjian (1996, p. 77) reports that "as far as long term debts were concerned, from the Tang dynasty on there was the consistent rule that total accumulated interest should not exceed the principal originally lent." An illustration of this is an edict of 1261 which was part of the Yuan administrative code. This rule appears to be like the variant of Alterum Tantum mentioned above, limiting the total amount of interest paid (rather than the arrears) to the amount of the principal:

In any case involving a private loan, the original contract shall be examined as evidence; the maximum profit shall not exceed the amount of principal originally lent.

In developing our model we invoked a limited liability clause, which protects the borrower from hold-up in the interim period. This prevents the lender from forcing the borrower who defaults after the first period to sign a fresh contract combining principal and accumulated interest into a fresh loan, thereby evading the intent of Damdupat. The statute we began to quote above sought to explicitly discourage this practice. It continues as follows:

If there is a contract to roll over the debt and extend its period, then that document shall be confiscated and destroyed by the presiding official, and the contract

${ }^{23}$ This version of Alterum Tantum is also mentioned by Zimmerman (1996, p. 169) as being prevalent in Rome in the post-Classical period. 
shall not be allowed to take effect. If the amount to be repaid has already been agreed upon, then the sum already paid shall be reckoned with the amount still outstanding, to make sure the total sum to be repaid does not exceed the amount of the principal plus an equal amount of interest.

Consistent with this, Junjian reports that the practice of combining interest and principal into a fresh loan, known as hui li wei ben, was prohibited in the Yuan dynasty and also in the Ming and the Qing. ${ }^{24}$

\section{Concluding Remarks}

In this paper we have analyzed a credit rule which limits interest accumulation to the amount of the original principal. Given its prevalence in Hindu, Roman, and Chinese legal traditions, we considered whether such a restriction can promote social welfare. Our model has identified a reasonable set of conditions in which it will do so: by reducing the repayment obtainable from "bad" borrowers it creates incentives for a monopolist lender to investigate project/borrower quality and allocate capital better. We showed that our argument holds in the world of standard debt contracts as well as in the world of general contracts when borrowers are overoptimistic. We also discussed alternative explanations for such a rule, and suggested that ours is most consistent with the stated intentions of policy-makers.

However, our discussion should not be taken to suggest, that, in practice, Damdupat-like rules necessarily improve social welfare. Though a monopolist lender may gain from investigating and communicating project/borrower quality, the lender's benefit may be lower in a competitive credit market: after he has communicated the information, the "good" borrower can borrow from someone else. It is also possible that Damdupat-like rules merely aggravate the problem of moral hazard, especially when they are not paired with institutions like Pious Obligation. In such situations they may make it even harder for the poor, who lack collateral, to access credit. Like many other well-intentioned interventions, restrictions on interest accumulation have costs as well as benefits. The former are easy to see in terms of existing models. In this paper we have clarified the latter.

Finally, we note that there are other credit rules with the same strategy of limiting interest accumulation, rather than the interest rate itself. One restriction mentioned

${ }^{24}$ There is also a mention in Kane (1946) of a Damdupat-like law in ancient Egypt. We have yet to locate the source he cites, so we cannot describe it in detail. 
in Chinese, Roman, and Indian sources, is a ban on compound interest. For instance, in later Roman law (Institutes of Justinian) compound interest, which was called usurae usurarum, could not be charged. The lender was also forbidden from trying to evade this restriction by combining principal and interest into a fresh loan (anatocismus coniunctus). The model developed in this paper can be used to analyze the ban on compound interest as well: like Damdupat and Alterum Tantum it will push lenders towards choosing more capable borrowers who can repay sooner. 


\section{APPENDIX}

We now present a variant of the model presented in section three to capture the basic intuition behind Damdupat as insurance to the borrower. The basic framework is identical to our model except that the lender has no means of ascertaining the quality of the borrower's project which is good $(g)$ with probability $p$ and bad $(b)$ with probability $(1-p)$. Consumption takes place at the end of period 2 and the borrower's utility is given by the following function:

$$
\begin{aligned}
u(C) & =C-\underline{C} & & \text { if } C \geq \underline{C} \\
& =-L & & \text { if } C<\underline{C}
\end{aligned}
$$

where $\underline{C}, L>0$. Hence, $\underline{C}$ can be interpreted as the subsistence level of consumption and the borrower suffers a welfare loss $L$ should the borrower's consumption fall below the subsistence level.

Now suppose that only standard debt contracts are enforceable. At any interest rate $r$, the borrower's expected utility from the project is

$$
p[S+(R-r) \triangle-\underline{C}]+(1-p) \chi
$$

where $\chi$ is given by

$$
\begin{aligned}
\chi & =S-r^{2}-\underline{C} & & \text { if } S-r^{2} \geq \underline{C} \\
& =-L & & \text { if } S-r^{2}<\underline{C}
\end{aligned}
$$

The borrower will accept the loan at interest rate $r$ if

$$
p[S+(R-r) \triangle-\underline{C}]+(1-p) \chi \geq S-\underline{C}
$$

Hence, the maximum interest rate $\bar{r}$ at which the borrower is willing to accept the debt contract is given by

$$
\bar{r}=\frac{p(R \triangle)-(1-p)(S-\underline{C}+L)}{p \triangle}
$$

If $\bar{r}<\triangle$, then the project will not be undertaken since the lender is not willing to lend at the interest rates that are acceptable to the borrower.

Imposition of Damdupat will ensure that the maximum repayment in the event of the bad outcome will be restricted to 2 (instead of $r^{2}$ ). Hence, if $S-2 \geq \underline{C}$, then Damdupat will protect the borrower from the downside risk of the project. In 
that case, the maximum interest rate at which the borrower is willing to accept the contract is given by

$$
\widehat{r}=\frac{p(R \triangle)-(1-p)(2)}{p \triangle}
$$

Comparing equations (11) and (12) it is easy to see that $\widehat{r}>\bar{r}$. The lender will be willing to lend at this rate if

$$
p \widehat{r} \triangle+(1-p) 2 \geq \triangle^{2}
$$

that is

$$
\widehat{r} \geq \frac{\triangle^{2}-(1-p) 2}{p \triangle}
$$

The intuition behind the above argument is straightforward: under the simple debt contract, in the event of project failure, the amount due accumulates at the compound interest rate and imposes a heavy burden on the borrower. Damdupat, by capping the maximum amount recoverable in the event of failure, provides the borrower insurance against such an eventuality. This is a general argument applicable for any risk averse borrower; our formulation above enables us to make the point in a simple way.

What if general contracts were enforceable? In that case the lender can always offer the contract $\widehat{r}, 2 .{ }^{25}$ Thus, an external imposition of Damdupat is unnecessary.

However, Damdupat might still play a useful role in the event that the borrower is overoptimistic. Suppose the borrower's perceived probability of success is $x(>p)$. Then, from equation (11) we know that the borrower will be willing to accept a simple debt contract at interest rate up to

$$
\bar{r}(x)=\frac{x(R \triangle)-(1-x)(S-\underline{C}+L)}{x \triangle}
$$

Note that $\bar{r}(x)$ exceeds $\bar{r}$ as $x>p$ and for sufficiently large $x$ we may have $\bar{r}(x) \geq \triangle$. In this case, the lender will not voluntarily offer a Damdupat-like contract. Imposition of Damdupat will play the role of a "mandatory insurance" which protects the overoptimistic borrower.

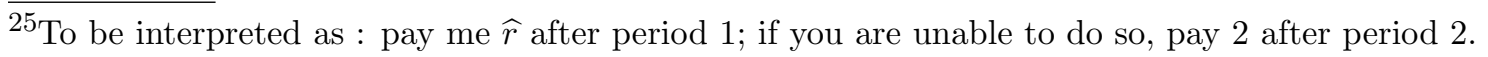




\section{REFERENCES}

[1] Banerjee, H. 1971. The Law of Debt in Ancient India. Calcutta: Sanskrit College.

[2] Basu, K. 1997. Analytical Development Economics: The Less Developed Economy Revisited. Cambridge: MIT Press.

[3] Carter, M. 1988. Equilibrium Credit Rationing of Small Farm Agriculture. Journal of Development Economics 28: 83-103.

[4] Catanach, I.J. 1970. Rural Credit in Western India 1875-1930. Berkeley, University of California Press.

[5] Coats, T. 1823. Account of the Present State of the Township of Lony: In Illustration of the Institutions, Resources, and c. of the Marratta Cultivators. Transactions of the the Literary Society of Bombay, Vol III, 183-279.

[6] Deccan Riots Commission. 1876. Report of the Committee on the Riots in Poona and Ahmednagar, 1875. Bombay: Government Central Press.

[7] Derrett, J.D.M. 1963. Introduction to Modern Hindu Law. Delhi: Oxford University Press.

[8] Gandhi, B. M. 2003. Hindu Law, Second Edition. Lucknow: Eastern Book Company.

[9] Hope, T.C. 1879. Deccan Agriculturists Relief Bill. Simla: Government Central Press.

[10] Kane, P.V. 1946. History of Dharmasastra: Ancient and Medieval Religious and Civil Law, Vol. III. Poona: Bhandarkar Oriental Research Institute.

[11] Hardiman, D. 1996. Feeding the Baniya: Peasants and Usurers in Western India. Delhi: Oxford University Press.

[12] Joshi, S. 2005. Farm loan straitjacket loosened, in Business Line, Internet Edition, April 20.

[13] Junjian, J. 1996. Legislation Related to the Private Economy in the Qing Dynasty, in K. Bernhardt and P.C.C. Huang eds. Civil Law in Qing and Republican China. Stanford: Stanford University Press.

[14] Kranton, R., and Swamy, A. 1999. The Hazards of Piecemeal Reform: British Civil Courts and Credit Market in Colonial India. Journal of Development Economics, 58, 1-25.

[15] Kumar, R. 1868. Western India in the Nineteenth Century. London: Routledge and Kegan Paul. 
[16] Lauterpecht, H. 1927. Private Sources and Analogies of International Law. New York: Longmans, Green, and Co.

[17] Manove, M., Padilla, A. J. and Pagano, M. 2001. Collateral Vs. Project Screening: A Model of Lazy Banks. Rand Journal of Economics, 32(4), 726-744.

[18] Manove, M. and Padilla, A. J. 1999. Banking (Conservatively) with Optimists. Rand Journal of Economics, 30(2), 324-350.

[19] MasCollel, A., Whinston, M. and Green, J. 1995. Microeconomic Theory. Oxford University Press.

[20] McAlpin, M.C. 1909 [1981]. Report on the Condition of the Sonthals in the Districts of Birbhum, Bankura, Midnapore and North Balasore. Calcutta: Firma Mukpadhyay.

[21] McPherson, H. 1909. Final Report on the Survey and Settlement Operations in the District of Sonthal Parganas 1898-1907. Calcutta: Bengal Secretariat Book Depot.

[22] Mulla, D. F. 1936. Principles of Hindu Law. Calcutta: The Eastern Law House.

[23] Olivelle, P. 2005. Manu's Code of Law: A Critical Edition and Translation of Manava-Dharmasastra. New York: Oxford University Press.

[24] Sohm, R. 1892 [2002]. The Institutes of Roman Law. Piscataway, NJ: Gorgias Press.

[25] Steele, A. 1868. Law and Custom of Hindoo Castes Within the Dekhun Provinces Subject to the Presidency of Bombay. London: W.H. Allen.

[26] Stein, P. 1999. Roman Law in European History. Cambridge: Cambridge University Press.

[27] Tellegen-Couperus, O. 1993. A Short History of Roman Law. New York: Routledge.

[28] Upton, A.F. 1998. Charles XI and Swedish Absolutism. Cambridge: Cambridge University Press.

[29] Zimmerman, R. 1996. The Law of Obligations: Roman Foundations of the Civilian Tradition. New York: Oxford University Press. 